\title{
GOOD GOVERNANCE
}

\section{AND ANTI-CORRUPTION BASED ON PATTERNS OF OMBUDSMAN MANAGEMENT}

\author{
Alireza Dadashzadeh \\ PhD candidate, Department of Law, Islamic Azad University, \\ Tehran Shomal branch, Tehran, Iran. \\ E-mail: dadatashzadeh@yahoo.com
}

\section{Ali Babaei Mehr}

Associated professor, Department of Law, Islamic Azad University,

Chaloos branch, Mazandaran, Iran.

E-mail: gatbabayee@ieuc.ac.ir

\section{Maryam Afshari}

Associated professor, Department of Law, Islamic Azad University,

Damavand, Iran.

E-mail: afshari2005m@yahoo.com

\begin{abstract}
Governance and anti-corruption policies and plans, which are supported by international organizations such as the World Bank, together determine all the vital goals in developing countries. There is no doubt about the desirability of good governance. On the other hand, while Western institutions try to force a version of good governance on countries like Iran, Islamic history has two brilliant applicable periods of divine rule. In Islam, two governments or favorable rulings have existed: one during the Prophet (peace be upon him), and the other during the period of Imam Ali (AS). Therefore, the critical questions can be classified as follows:

How vital are these goals in terms of both development goals and the necessary governance preconditions for development? Are these goals really achievable in developing countries? What are the indicators of the Islamic system in fighting against corruption and the achievement of good governance? Does a focus on these issues distract us from the more important and unattainable reforms that speed up the achievement of governance goals?

Generally, focusing on the corruption and implementing good governance reforms in developing countries diverts the attention from practical policies. Although, there are many types of corruption in developing countries, it is vital to create the necessary governance capacities to identify and limit the most destructive types of corruption. Therefore, there is a framework for identifying various types of corruption, in order to set priorities for institutional reform and successful anti-corruption policies. This paper is based on descriptive and analytical methods and all data were collected in the form of documentary studies.
\end{abstract}


Keywords: Good governance; corruption; developing countries; policies; management.

Citation: Dadashzadeh, A., Mehr, Ali B. \& Afshari, M. (2019). Good Governance and Anti-Corruption Based on Patterns of Ombudsman Management. Public Administration Issue, no 6, (Special Issue II, electronic edition), pp. 41-60 (in English); DOI: 10.17323/1999-5431-2019-0-6-41-60.

\section{Introduction}

Obviously, the role of governance and institutions in increasing development and reducing poverty in developing countries is vital, and also there is no common set of institutions in which all successful developing countries share this issue in this regard. In most successful developing countries, there is significant and certain corruption, and governance in the early stages of development in these countries has encountered significant difficulties. However, these countries have good potential for proper governance, which allows governments to create conditions where the rapid growth and stable political legitimacy of the state are guaranteed. Therefore, in these countries, sustained pressure is both necessary and desirable in order to reduce corruption, but these goals cannot be achieved unless adequate attention is paid to the governance capacity that is needed for sustainable growth (Jasabi \& Nafari, 2009).

For good governance, international institutions and their experts determine indicators in order to assess whether the rulers of developing countries govern their community affairs based on these patterns or not. If a country works according to these indicators, it will succeed in this pattern and, as a result, will benefit from all global assistance and international institutions, such as the World Bank, the UN Development Program and the International Monetary Fund. But if they do not work according to these indicators, they will be deprived of this support and assistance (Huther \& Shah, 2000). Similarly, according to a document released by the World Bank in 2006, good governance has six indicators (World Bank, 1993): responsiveness, political stability, government effectiveness, quality of laws and regulations, rule of law, and corruption control. According to the World Bank, the closer the country is to these indicators, the higher their economic growth rate will be and therefore the more efficient their private sector growth will be. In addition, total mortality is reduced and the inflow of foreign capital is increased significantly.

On the other hand, one of the goals of establishing a government and ruling in Islam is to address the rights of the deprived and the defense of the oppressed. Imam Ali (AS) states the reasons to accept the government as follows: "Our Lord! You know, what we did was not to get the royal possessions, nor to get anything from the world's post goods, but because we were able to restore the lost signs of your religion and restore peace and reform in your towns so that your oppressed servants be in safe and the rules and regulations that have been forgotten be reenforced." Therefore, it can be concluded that the spread of spirituality, security and prosperity in society (especially the rights of the oppressed people) and the rule of law, were the main goals of Imam Ali to establish the government.

According to the models presented today, some types of anti-corruption reform and governance programs have been chosen by some countries as a part 
of their sustainable development strategy, however, the idealistic and desired goals of good governance are neither necessary nor suitable for accelerating and sustaining development. The challenge for developing countries which want to implement institutional reforms and anti-corruption strategies is to learn the lessons from international experiences and also implement the programs and policies that are both feasible and appropriate for their country's circumstances. The governance and anticorruption programs that some developing countries are currently pursuing do not fully achieve these goals and may even be inaccessible and very ambitious, and divert the attention from the major governance reforms (Kermani \& Baskhah, 2009).

\section{Good governance and anti-corruption policies}

Corruption usually occurs when government officials violate the law for their personal interests. Bribery and extortion are two of the worst kinds of corruption (Gharani et al., 2010). Some other types of corruption, such as the allocation of public resources to particular individuals for political interests, can also be categorised in this group. Corruption in most developing countries results in significant costs in many areas (for example, wasted development plans, changing the direction of programs and resources used for effective investment, creating problems with transparency and the normal functioning of the markets, etc.). In recent years, comprehensive analysis of the governance role in improving the development prospects of developing countries has proven the effectivity of corruption caused by international institutions (Gholipour, 2005). As a result, this new analysis of corruption can be a part of an integrated analysis about the good governance. The main subjects of this analysis are from anecdotal economics, which defines an efficient market as a market with low transaction costs. Interchange costs are the costs of transactions and activities which in particular include bargaining costs and execution of contracts (Jasabi Nafari, 2009). If these costs were too high, the markets would be inefficient and the necessary transactions such as long-term investments would not be performed. Thus, good governance conditions, which are required in developing countries, can be theoretically recognized as a precondition or tools to guarantee the development process because they have the necessary political and institutional conditions to ensure low transaction costs in the market-based economies.

Weak performance in economic development is described based on inefficiency and high costs of the economic markets. In contrast, the continuation of inefficient markets is based on government interventions that reduce welfare and, more importantly, weak property rights which lead to maintenance and implementation of costly assets. This is followed by the continuing instability of property rights and welfarereducing interventions in developing countries based on corruption and economic rent (Knack \& Keefer, 1995). But the question is that while the number of people who benefit from the corruption and economic rent is low, how are they able to continue their activities to the detriment of the majority? The answer is that this majority is either weakly organized or there is no democratic accountability or responsibility, or if it exists, it is very weak; and this allows the minority to exploit the majority. Poverty and deprivation restrict the institutional capacity of the majority and, consequently, the system will remain in poverty with unsustainable development. 
From this perspective, the good analysis of organizational governance creates a set of parallel political priorities that should be followed simultaneously to escape from the poverty trap. This set of interrelated policies combines the economic reforms with the institutional and political reforms, which is known as the "good governance program" (Midri, 2002). However, by studying good governance (Table 1), it seems that instead of a simple focus on economic reforms such as liberalization, it is necessary that institutional reforms, which enhance the stability of intellectual property and the rule of law, anti-corruption reform, and the widespread fight with economic rent and reforms to promote accountability of governments is pursued at the same time. For this reason, it is clear that anti-corruption reform plays an important role in the new reform agenda.

Table 1

\section{The Internal relationship of good governance reform program}

\begin{tabular}{|l|l|l|}
\hline \multicolumn{1}{|c|}{$\begin{array}{c}\text { Policies for fixing property } \\
\text { rights in the country }\end{array}$} & $\begin{array}{c}\text { Anti-corruption } \\
\text { and economic rent policies }\end{array}$ & $\begin{array}{l}\text { Government accountability } \\
\text { improvement policies }\end{array}$ \\
\hline $\begin{array}{l}\text { Policies to improve the } \\
\text { rule of law, reduce the risk } \\
\text { of expropriation, strengthen } \\
\text { the judiciary }\end{array}$ & $\begin{array}{l}\text { Anti-corruption policies, } \\
\text { the release of WTO restrictions } \\
\text { on subsidies and financial } \\
\text { obligations of the International } \\
\text { Monetary Fund }\end{array}$ & $\begin{array}{l}\text { Poverty reduction and PGBS } \\
\text { policies (in some countries) } \\
\text { and accountability and } \\
\text { decentralization reform }\end{array}$ \\
\hline
\end{tabular}

\section{The influence of good governance on improving economic growth}

According to the empirical observations, it should be noticed that there is a weak relationship between the discussed conditions in the good governance program and the improvement of economic growth, but there are more important governance conditions that are essential for accelerating and stabilizing economic growth, none of which were identified in a good governance approach. Studying the evidence suggests that, regardless of the potential benefits of good governance, its conditions and in particular its role is not attainable in reducing the corruption in most developing countries (Khan, 2006a). The primary problem for any comparative empirical investigation is that the quality of governance, and particularly corruption, cannot be measured directly. Therefore, it is necessary to define relevant indicators by using mental and subjective judgments, which both have bias and subjective problems (Farrokh Seresht, 2004). However, some studies have shown that, even if these indicators are used, some solid and sound findings that derived from these indicators to support the good governance program cannot be justified. According to the extensive econometric studies that partly show the relationship between the governance indicators, such as corruption, rule of law and other good governance and economic performance, this conclusion is important. For example, there is a stronger relationship between the quality of governance and income, thus it can be concluded that richer countries have better governance and less corruption. But in such studies, it is very difficult to paint an accurate picture because in general it can be said that higher incomes along with high- 
er levels of development make it possible to create good governance conditions. The corruption and other governance indicators will be accepted as policy objectives if a relationship between the governance indicators and economic growth are established (Knack \& Keefer, 1995).

In the empirical studies, the most important issue is that we should compare similar issues, and so it is very difficult to find the countries that differ only in terms of the governance index. Specifically, countries are at different levels of development, and in order to measure their economic performance they should be at least divided into developed countries (with high incomes) and the rest as developing countries. It seems that the greatest relationship between good governance and economic performance appears when all countries are classified in just one group. But the result would be more interesting when it comes to dividing these countries into two categories - developed countries and the rest of the world - and grouping the latter into two convergent and divergent countries. The convergent countries are those countries with standards of living similar to the advanced countries and the level of the growth rate in these countries is equal or even higher than the advanced countries. On the other hand, the divergent countries are those countries in which the average growth rate is much lower than that of the developed countries. The result is that the governance differences between the convergent and the divergent developing countries are likely to be significant, but these differences are not included in the good governance indicators, which traditional policy makers usually focus on.

The IRIS Center's governance and corruption indicators are shown in Tables 2 to 5 . While all governance indicators have a well-known subjective problem, these indicators are widely used and are very appropriate to illustrate the most important features of the problem. If we use the World Bank benchmarks provided by Kauffman and his colleagues, the same result will be obtained. But the World Bank indicators have only been available since 1996. The IRIS governance index has been available since 1984 and it is a combination of five indicators of "government corruption, rule of law, quality of bureaucracy, non-compliance with government contracts and the risk of foreclosure" (Knack \& Keefer, 1995). This index is between zero (lowest score) and 50 (highest score). In addition, the index of the corruption between zero (lowest score) and six (highest score) was defined and used in this research work separately.

Table 2

The governance and growth for 1980-1990

(Intellectual Property Index varies from 0 (the worst case) to 50 (the best case))

\begin{tabular}{|c|c|c|l|}
\hline $\begin{array}{c}\text { Convergent } \\
\text { developing } \\
\text { countries }\end{array}$ & $\begin{array}{c}\text { Divergent } \\
\text { developing } \\
\text { countries }\end{array}$ & $\begin{array}{c}\text { Advanced } \\
\text { countries }\end{array}$ & \\
\hline 35 & 53 & 24 & Number of countries \\
\hline 23.7 & 25 & 47 & The average property rights index in 1990 \\
\hline $9.5-40$ & $38.3-10$ & 50.32 .3 & Registered property index domain \\
\hline 3 & 0.4 & 2.1 & $\begin{array}{l}\text { The average per capita GDP growth rate per } \\
\text { capita in 1990-2003 }\end{array}$ \\
\hline
\end{tabular}


Table 3

The governance and growth for 1990-2003

(Intellectual Property Index varies from 0 (the worst case) to 50 (the best case))

\begin{tabular}{|c|c|c|l|}
\hline $\begin{array}{c}\text { Convergent } \\
\text { developing } \\
\text { countries }\end{array}$ & $\begin{array}{c}\text { Divergent } \\
\text { developing } \\
\text { countries }\end{array}$ & $\begin{array}{c}\text { Advanced } \\
\text { countries }\end{array}$ & \\
\hline 12 & 52 & 21 & Number of countries \\
\hline 3 & 2.6 & 5.4 & The average property rights index in 1990 \\
\hline $1-5$ & $0-6$ & $6-3$ & Registered property index domain \\
\hline 3.5 & -1 & 2.2 & $\begin{array}{l}\text { The average per capita GDP growth rate per } \\
\text { capita in 1980-1990 }\end{array}$ \\
\hline & & & \\
\hline
\end{tabular}

Table 4

The governance and growth for 1980-1990

(Intellectual Property Index varies from 0 (the worst case) to 50 (the best case))

\begin{tabular}{|c|c|c|l|}
\hline $\begin{array}{c}\text { Convergent } \\
\text { developing } \\
\text { countries }\end{array}$ & $\begin{array}{c}\text { Divergent } \\
\text { developing } \\
\text { countries }\end{array}$ & $\begin{array}{c}\text { Advanced } \\
\text { countries }\end{array}$ & \\
\hline 35 & 53 & 24 & Number of countries \\
\hline 3 & 3 & 5 & The average property rights index in 1990 \\
\hline $0-5$ & $5-0$ & $6-2$ & Registered property index domain \\
\hline 3 & 0.4 & 2.1 & $\begin{array}{l}\text { The average per capita GDP growth rate per } \\
\text { capita in 1990-2003 }\end{array}$ \\
\hline & & & \\
\hline
\end{tabular}

Because all of the primary indicators of governance have been prepared since 1984, using these indicators for 1980s data is less accurate than that of the 1990s. Based on our studies, it is expected that a higher per capita income results in better governance, and if a country grows rapidly for a period of time, the higher incomes provide better governance characteristics for that country, even if these characteristics do not exist at the beginning of this period. But if we do not have enough information in this regard, we might be wrong to conclude that this better governance leads to better growth, even if the cause of this growth is something else. As expected, the obtained data shows that developed countries, in comparison with developing countries, get a better score in all governance indicators. The comparisons between the developing (high growth) and divergent (low growth) countries are very interesting. The data revealed that the difference in the governance indicators for both groups is negligible in terms of both general governance and specific indicators. Thus, here the results for the corruption indicators are shown on the basis of difference in the elements of the governance indicators. According to Table 2, which is related to the 1980s, the data obtained for all countries show a positive and weak correlation between good governance and economic growth. However, a closer look suggests that the governance indicators in the convergent developing countries are slightly better 
than those of the divergent countries. It is important to note that both countries are significantly worse than the advanced countries (Khan, 2006b)

There is a very small difference between the convergent and the divergent developing countries but, as shown in Table 3, the difference in the growth rates among the convergent and divergent developing countries is associated with a very insignificant difference in the quality of the governance. By looking at the data related to the 1990s (see Table 3), it can be observed that there are no significant differences between the convergent and the divergent developing countries, but during this decade, the indicators of the governance of the convergent developing countries in comparison with the divergent developing countries has been weaker.

The convergent developing countries achieved a relatively better score than the divergent developing countries in terms of corruption index in the 1980s, but both countries have a worse situation than the advanced countries (see Table 4). However, in the 1990s, this insignificant difference between the convergent and the divergent developing countries is completely eliminated, as seen in Table 5.

Table 5

\section{The governance and growth for 1990-2003}

(Intellectual Property Index varies from 0 (the worst case) to 50 (the best case))

\begin{tabular}{|c|c|c|l|}
\hline $\begin{array}{c}\text { Convergent } \\
\text { developing } \\
\text { countries }\end{array}$ & $\begin{array}{c}\text { Divergent } \\
\text { developing } \\
\text { countries }\end{array}$ & $\begin{array}{c}\text { Advanced } \\
\text { countries }\end{array}$ & \\
\hline 35 & 53 & 24 & Number of countries \\
\hline 3 & 3 & 5 & The average property rights index in 1990 \\
\hline $0-5$ & $5-0$ & $6-2$ & Registered property index domain \\
\hline 3 & 0.4 & 2.1 & $\begin{array}{l}\text { The average per capita GDP growth rate per } \\
\text { capita in 1990-2003 }\end{array}$ \\
\hline
\end{tabular}

In the 1990s, the average indicator of corruption in the convergent and divergent developing countries is quite similar. However, the score of both countries is significantly weaker and lower in the corruption index compared to the advanced countries (Khan, 2006a,b,c). In general, it can be said that the positive relation between corruption and the other indicators of governance and the economic growth in the obtained results is misleading. This does not mean that there is no significant difference between the governments of the convergent and divergent developing countries, rather it means that important differences in their governance characteristics are not well recognized by the analytical framework of the governance.

There is no significant difference between the convergent and the divergent developing countries in terms of the governance characteristics, but there are too many differences in their economic performance. The challenge that the divergent developing countries are faced with is how to boost economic growth, while the challenge for the convergent developing countries (Group 2) is to sustain the previously achieved growth. Under the Good Governance Program, the divergent countries (Group 1) can become advanced countries (Group 3) by implementing 
good governance reforms and moving to the top of the chart. But this suggestion is based on the above evidence, not on historical observations of developing countries, whereby they first improved their governance characteristics and then increased their growth rates, even as high as the advanced countries (which is described as good governance).

So much historical evidence shows that the challenge for the divergent countries is to recognize policy and governance changes. This recognition allows countries to move from Group 1 to Group 2. The challenge of the Group 2 countries is the better understanding of what they have achieved through good luck. It means they can act in a manner that can sustain their good performances over the time. Undoubtedly, for the second group, a good time for governance reform is when their growth has begun, which finally allows them to move from Group 2 to Group 3. But in the poorer countries, there is little evidence that proves the second phase of the reforms is fully implemented.

A lot of research has been done on the management potential of Group 2. These studies identified some of the specific governance capacities of the convergent developing countries. The proposed capacities can be summarized as: the capacities of support funds and the resources of the main productive sectors, the directing of funds and resources to these sectors, helping these sectors to achieve more advanced technologies, market regulation to increase productivity in the productive sectors, and the social stability and the rule of law through redistributive policies. Unfortunately, in different countries there is no set of institutions that achieved these goals. For example, the policies and strategies that are followed in South Korea, Malaysia, China, and India are completely different from each other.

\section{Good governance in Islam}

In Islam, the ruler of Islamic society that is called the king or sultan does not mean possession and domination, but one is confronted with such words as "Imam" (ruler and leader) and "governor". The leader and Imam are the ones who are leading the community and nation and they themselves are the leader of this movement. Provincial governorate implies the meaning of continuity. The Governor of Ummah (nation) and people is the person who is responsible for public affairs. The ruler in Islam is the one who is at the head of the government and is obliged to carry out a divine and important duty. He is the one in society who carries the heaviest burden. On the other hand, there are people that are supposed to be respected with all their aspirations and spiritual values and also ideals. Imam Ali's view about the government is a divine outlook. An outlook that is fundamentally different from the power-based outlook. At the beginning of his ruling, Imam Ali (AS) accepted this great responsibility because of getting the oppressed right from the tyrant.

\section{Common anti-corruption policies}

The greed of government officials is one of the main reasons for corruption as they have the power and authority to bribe citizens or disrupt their affairs. These are people whose law-breaking is not properly controlled nor punished. Therefore, 
bureaucrats and politicians are more likely to engage in corruption to make themselves stronger. Many studies have been conducted on the causes of corruption. Although in these studies there are differences in the analysis of the corruption, there are similarities among them about the main motivations of the corruption, which allows us to describe it in the general framework of the theory of greed and power (Rose-Ackerman, 1978). To fight against corruption, the appropriate policy response is generally based on the fight against the corruption which has motivations expressed in the greed and power theories. The following cases can be summarized as the indicators and policy responses:

1. Reducing the power and authority of government officials through liberalization and privatization.

2. Increasing the salaries of government officials so that they can resolve their life problems.

3. Increasing the rule of law in order to prosecute or arrest bureaucrats and politicians.

4. Encouraging higher transparency in government policy-making and decisionmaking through the implementation of democracy, decentralization, and also creating and encouraging civil society watchers.

However, corruption is not entirely due to the factors expressed in the power theory and greed in the developing countries, but the adoption of such indicators and anti-corruption policies in many developing countries can significantly reduce corruption. Although those effects are not denied, the comprehensive studies and also the case studies showed that many of the major tools for policy-making identified in the power theories and greed are limited. For example, numerous studies have been performed in the Indian subcontinent and Eastern Europe which show that policies reducing government authority through liberalization and privatization have a negligible effect on reducing corruption in developing and transitional countries. Indeed, in many cases, privatization and liberalization have been accompanied by significant increases in corruption (Harriss-White $\&$ White, 1996).

In this regard, it seems unlikely that an increase in the salaries and the rewards of government officials (the theory of power and greed) would not be effective unless the government officials lose their positions by committing corruption. Adopting such support requires a profound change in political and legal structures. Although there is no doubt that there is a relationship between increasing the salaries of public servants and reducing corruption, the implementation of such policies is unlikely and too low (Besley \& McLaren, 1993).

While there are many plans to increase the rule of law in developing countries, there is little evidence about the influence of this policy. The empirical evidence proves how far the promotion of the rule of law in developing countries has helped reduce corruption or achieve other development goals (Carothers, 2003).

On the other hand, studying the strategy of promoting transparency and creating new institutions, such as an Ombudsman, facilitates protection and support by outside institutions. This is not surprising because this is the area where many international policies are focused. In a study conducted by Huther and Shaw for the Evaluation Department of the World Bank, it was discovered that in developing countries with low levels of the governance, many strategies such as intro- 
ducing the ombudsman and increasing public awareness of corruption, are not effective (Huther \& Shah, 2000). However, their results indicated that reducing the government size, increasing citizen participation and promoting the rule of law (to some extent) in such countries are the best strategies.

According to the relationship between democratization and corruption, it is believed that corruption is lower in good democracies. Short-term democracy has little effect on corruption, but the long-term effects can also be explained by the fact that only economically successful countries can create long-term sustainable democracies.

The regression analysis carried out in the developed and developing countries revealed that decentralization has a significant effect on the reduction of corruption. At the same time, these studies show that when the regression analysis is conducted only for the developing countries, no relationship exists between the decentralization and the reduction of corruption. The above result is more crucial because it involves analyzing the advanced and developing countries in a regression, which had a major conflict with the obtained results.

\section{The prevalence of corruption from the Islam perspective}

In the Sharia of Islam, corruption and expediency are the criteria and benchmarks for determining ordinances and rulings. One of the main factors that lead to the government's survival and strength, and also to protect society from negative deviations, is to benefit from a comprehensive and dynamic law. This law must be such as to fight with even the lowest deviation and corruption, which impairs the supreme value of human beings, and therefore the corrupters in society do not feel safe. The rules must have the necessary capability and comprehensiveness in such a way that the punishment must be commensurate with the related crime. In such law, the offender must be treated fairly while crime repetition has to be prevented effectively. The Islamic government has based its rules on divine laws due to the defects in human laws and the existence of trial and error therein.

\section{Corruption in Islamic government}

Corruption has a special meaning in each science. In jurisprudence, one of the main topics is "denying corruption" and whether the prohibition of an act leads to its corruption or not. In this situation, corruption is against correctness, where correctness means full and effective and corruption means defective and ineffective. According to the various aspects of jurisprudence, corruption has different meanings. In worship, which is intended to be cherished, corruption means the violation of action, thus preventing the action causing the corruption and disorderly effects of it. In transactions, corruption means violating a contract. In criminal jurisprudence, corruption means unlawful acts and refers to any act of sin that is defined under some of these meanings.

\section{Structural motivations for corruption in developing countries}

Studying the theory of greed and power proved that the theory ignores some of the structural problems that developing countries face. The problem is the high level of corruption in developing countries. Understanding the structural stimuli 
of corruption makes it possible to adopt a more rational stance on anti-corruption policies in developing countries and also to design appropriate anti-corruption policies to deal with all kinds of corruption. These stimuli include as follows:

\section{A) Corruption related to government intervention}

One of the common principles for fighting against corruption is the prohibition of private intervention in the government sectors. In order to accelerate development, such an action is not only necessary, but also an opportunity for extortion by official authorities. It is important to note that this assumption is incorrect. In order to accelerate economic development, the management of some sensitive interventions is necessary. Such interventions have been used by all successful Asian developing countries (Khan, 2006b). These interventions are in addition to the interventions that governments need to create a flexible basis for maintaining prosperity. Many of these interventions are beneficial and the governments need to be able to capture, recognize, maintain and manage them effectively.

Although liberation may not solve this problem, some anti-corruption strategies that are supported by the current anti-corruption program can be used. For example, improving the rule of law or increasing the salaries of official agents can help reduce corruption in areas where the government has sensitive tasks. However, some evidence suggests that these strategies are unsuccessful and require a long time to run. Therefore, other effective strategies should be adopted to deal with destructive bribery and malicious economic rent (Khan, 2006a).

Surprisingly, this answer may be similar to the answer that which advanced countries have used in dealing with economic rent and destructive bribery. In advanced countries, governments play an important role in managing the economies, and this inevitably leads to incentives for extensive economic rent. The economic rent becomes legalized in advanced countries because the interventions and economic rents have a legal infrastructure. This leads to economic rent being formed in a legal framework (e.g. lobbying industry groups to increase their benefits within the described limits). According to our definition, this economic rent with the illegal forms in developing countries is considered as corruption. Modern sections are emerging in developing countries and the helping interventions are often informal with no broad political support. However, it should be noted that this issue does not apply to all developing countries, especially the more developed ones.

Therefore, in this regard, the distinction between the desired outcome of the intervention and the cost of the economic rent of this intervention should be distinguished. Economic rent does not seriously affect the outcome of the intervention, but the resources used for it are considered as a social expense. Nevertheless, the effect of the intervention can be positive. The government's ability to ensure the effective intervention and the institutions, which can limit the cost of the economic rent, are both important in this case. However, the former is more important because no value exists in these sensitive areas to limit the cost of the economic rent, but achieving most of the intended results of the intervention fails. Therefore, the priority of developing countries should be to strengthen the government capacity to help economic growth in the vital areas, such as access to technology or the preparation of important infrastructure for the manufacturing sectors. Neverthe- 
less, corruption can be significantly reduced in all developing countries by recognizing and legitimizing these government interventions in the areas that they have not been previously regulated. Simultaneously, the policy-making should strengthen the government's regulatory capacity in order to manage and regulate the intervention and economic rent. It can be said that while all developed countries still have some degree of corruption, albeit due to their high capacity in these sectors, the corruption does not disrupt the government's core duties. Therefore, the main focus of anti-corruption strategies should be to strengthen and reinforce these capacities, but this item has been underestimated in developing countries' development programs.

\section{B) Structural Motivations of Political Corruption and Financial Constraints}

It seems that dealing with other corruption motivations in developing countries may be even more difficult, and governments should propose short-term strategies to address the destructive effects of this kind of corruption. One of the fundamental problems of governments in developing countries is to maintain political stability in a situation where financial resources are severely limited. Maintaining political stability requires the availability of sufficient financial resources to help areas that have political power or social legitimacy. However, this issue is ignored in the allocation of income and resources, through economic processes. The tax in developed countries ranges from $35 \%$ to $50 \%$ of the gross domestic product, which is mainly distributed in different areas to maintain social cohesion and political stability. On the other hand, in developing countries, only $10 \%$ to $25 \%$ of the gross domestic product is assigned to tax due to the small size of the modern sectors and institutional weaknesses. In most developing countries, after paying employee salaries, no money is left to provide essential services or to create vital infrastructure for development (Khan, 2006b). In many developing countries, the main development cost is financed through domestic bonds and also external financial flows, and, as a result, little financial space remains to achieve the required stable redistribution of funds. Nevertheless, strong institutions exist in the developing countries, which want to maintain the redistribution and political stability. This goal is not usually achieved by limited redistribution through the budget. This structural problem explains the importance of PatronClient networks in developing countries. The transfer of non-budgetary resources through strong support networks to powerful areas is a common mechanism for maintaining the political stability in all developing countries. Unfortunately, this process has the potential to exacerbate corruption because political power is used extensively to benefit individual followers in order to keep the political supporters in power through this mechanism. The political scientists and sociologist have shown hundreds of different social gaps that have been formed around the PatronClient categories in the developing countries. However, clarifying the reasons for the widespread presence of the Patron-Client bands in all developing countries requires a more comprehensive explanation regardless of the cultural history, economic strategies and even political institutions (Khan, 2006b). An important part of this explanation in developing countries is the economic problem of maintaining political stability during a financial shortage. Due to the lack of resources, it is 
not possible to provide the required resources for all the deserved groups in all domains. So, supplying the required resources should be carried out through the networks unclearly. If these resources are not available in the budget, the governments are forced to provide it through non-budgetary means, which involve corruption. Therefore, increasing the resources to create the political stability can lead to the political corruption in all important areas (Khan, 2006a).

\section{Figure 1: Motivations of political corruption in developing countries}

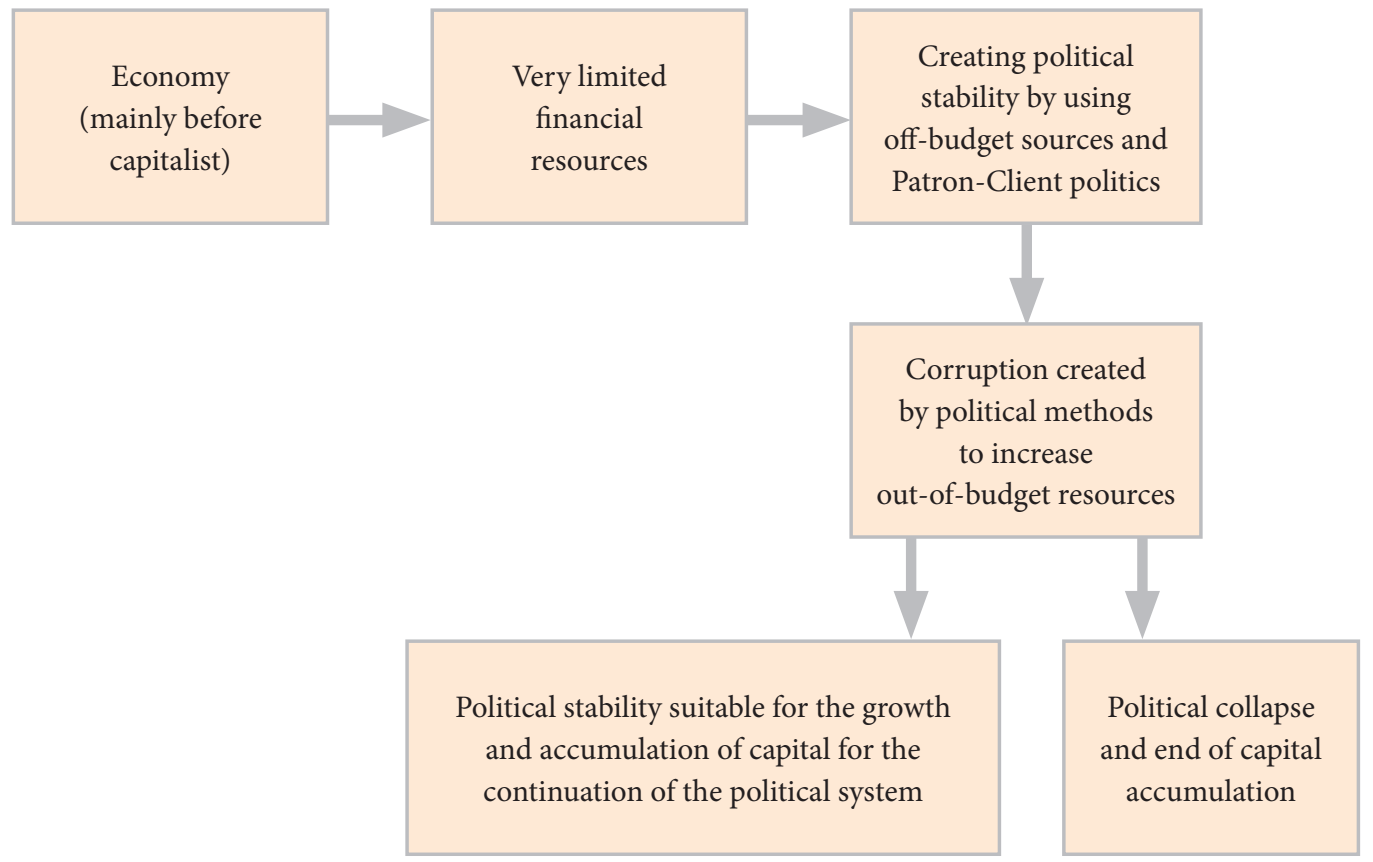

If greed and power allow the spread of some of these cases of corruption, they will also allow government officials to benefit from these systematic stimuli. Still, the power of authority or the greed of officials cannot be regarded as the main motive for this type of corruption. As illustrated in Fig. 2, the main drivers of this type of corruption are financial constraints and the political stability. The financial limitations cannot be restricted as long as the possibility of creating this kind of corruption is relatively eliminated.

Incidentally, although the supportive policy and associated political corruption are common in all developing countries, the results of these issues are completely different in regards to economic development. Hence, in some cases this policy can lead to political stability and thereby lead to growth, but in other cases it will fail. The reason for the difference in the success and failure in some developing countries is not the lack of political corruption. This is due to the difference in organizing the Patron-Client politics and also managing dispersed demands.

In this regard, our analysis of the motivations of political corruption is compatible with the evidence of the political corruption and the failure of the reforms in all developing countries. Reformist governments, which are chosen from among 
the most well-known candidates and substituted by corrupt governments, seem to be corrupted by exerting pressure on the existing order in a relatively short period of time. This example shows that the existing robust structural stimuli are so strong that they will finally overcome the anti-corruption policies. These experiences show that reforming the transparency and accountability system by addressing financial constraints and achieving political stability through transparent financial transfers on its own cannot solve the problem of corruption. There are also many case studies about corrupt politicians who have defeated honest politicians in elections even when their corruption is revealed and there is no transparency in their functioning.

It should be noted that this argument does not mean that the fight against political corruption is impossible, but rather it means that this fight must not be condemned to failure and that its results can be achieved at future. Reforming and corrective measures in governance should be focused on guarantee the preservation of political stability. It also should be focused on the destructive effects of political corruption, which seriously threaten social and human development and eliminate the stability and legitimacy of the government. The reforms that are appropriate for solving those problems are valid only for a particular country, and it is not possible to provide similar anti-corruption strategies for all countries.

It is worth mentioning that the difference between developing countries in the means of applying Patron-Client politics strongly depends on the subtle differences in the organization of political parties, and the Patron-Client groups. The historical experiences in changing the direction of the economic approach (e.g. South Korea in the early 1960s and Malaysia in the early 1970s) are closely related to changes in the organization of domestic politics in the countries. The examples demonstrate the possibility of achieving political stability even if the policy of support is not immediately eliminated. Current government programs and policies do not provide any starting point for developing countries to determine their governance weaknesses or to help them to implement reformist governance plans in order to address the more destructive dimensions of political corruption.

\section{C) Weak ownership and exchanges (transactions) with non-market methods}

One of the main structural problems in many developing countries is not enough protection of private property due to limited government resources. In most of the commonly used analyses of governance and corruption in developing countries, it is widely assumed that ownership rights can be substantially supported through governance reform and the reduction of corruption. This analysis ignores this economic reality that the establishing of a stable national comprehensive system for ownership rights is costly. Developed countries also achieve significant stability in ownership rights at the last stages of their development (when most assets reach their highest levels of productivity) (Khan, 2006b).

The results of the new institutional economy, provided by Douglas North, show that the protection of ownership rights is costly. These costs are considered as transaction (exchanges) costs, and the new institutional economy emphasizes that the exchange costs in advanced economies account for roughly half of all economic activity. The cost of exchanging for an efficient economy is much lower than 
the exchange costs of other countries. For an efficient market-based economy like United States, exchanging (transaction) costs for its dealers may be low at the exchange place (the definition of an efficient market), but the total exchanging costs for the whole economy are not low. Of course, these exchange costs can be paid because almost all assets in a developed country are productive (as defined) and the owners can pay personal costs and taxes based on the legal and security system, which ensures the low exchange costs.

By analyzing a developing country, it must be acknowledged that most of the assets have low productivity and the cost of supporting them is high. It is not surprising that all developing countries are suffering from weak and frivolous property rights (ownership).

The factors for this instability can be seen in Figure 2. When most of the assets in one country do not yet have high productivity, the ownership rights cannot be defined and considered effectively.

\section{Figure 2: Factors for transferring assets with out-of-market methods in developing countries}

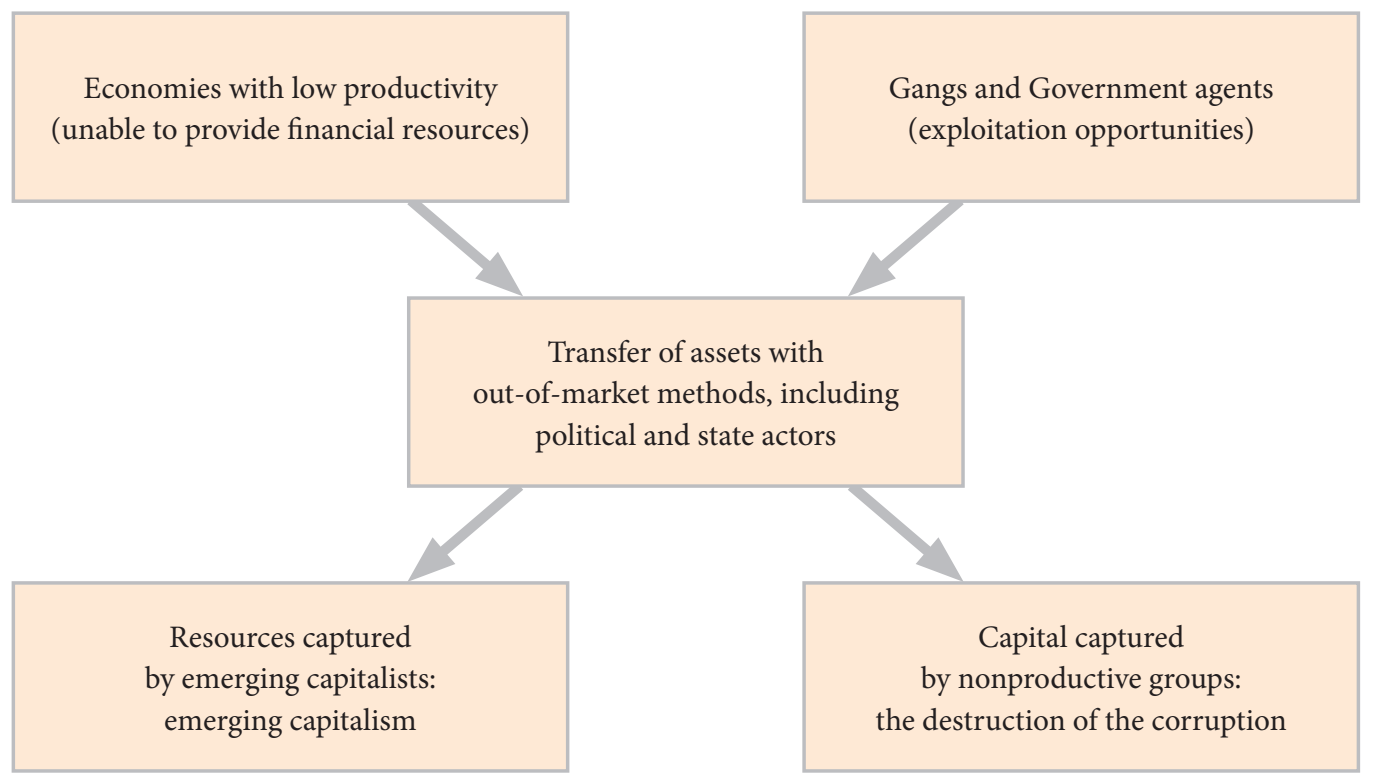

Developing countries are facing much more instability in property rights (ownership) than developed countries. This is not entirely due to greed or misuse of power by their government officials. When the ownership is not secure and the exchange (transaction) costs are high, many exchanges (transactions) will inevitably be costly through the market. Thus, in developing countries the out-of-market distributors are more visible everywhere than in developed countries. These transactions that are not conducted in a free market include the high-level misuse of political power, allocating state land for development and extensive use of the authority to allocate state resources. These processes are structurally essential in developing countries but eventually may lead to abuse 
and corruption. But these processes cannot be stopped just like the Patron-Client politics and political corruption, simply by addressing the greed and power of government officials, because there are stronger structural factors which stimulate these processes. The consequences of this exchange out of the market can either lead to a successful transition to a modern capitalist economy, or to the destruction of resources.

The case studies reveals that many Asian and African developing countries with low growth rates (when compared to China) are generally facing a high degree of conflict over ownership in their economies. However, the consequences for the economies of these countries are very different from each other. In countries such as China, the profits of the investors into the productive sectors have considerable stability (if they are always profitable). However, comparing the ownership rights in China with those of other countries proves that the majority of the Chinese owners are likely to be confronted with the challenge of ownership rights.

On the other hand, in poor countries, the main problem is that the generative entrepreneurs often face uncertainty in their expectations, and as a result, the level of investment between them is low. This analysis shows that a more significant set of governance reforms is required, which can create sustainable expectations in the critical sections in order to accelerate investment and growth. Instead, in poor countries without sufficient economic resources, trying to implement the reform programs to achieve stability in the ownership rights likely leads to the failure and abandonment of the programs.

\section{D) Exploitation and expropriation}

The worst and the most destructive type of corruption in most developing countries is government corruption. According to government corruption, the government officials use their political and military power to seize the citizens' property. The Patron-Client politics in developing countries and the exchange of assets by out-of-market methods are a form of exploitation which hinder investment and development. The critical boundary between maintaining political stability and damaging sustainable development in the patterns of Patron-Client politics is vague and ambiguous (see: Fig. 3).

\section{Figure 3: The main motivations of exploitation and expropriation}

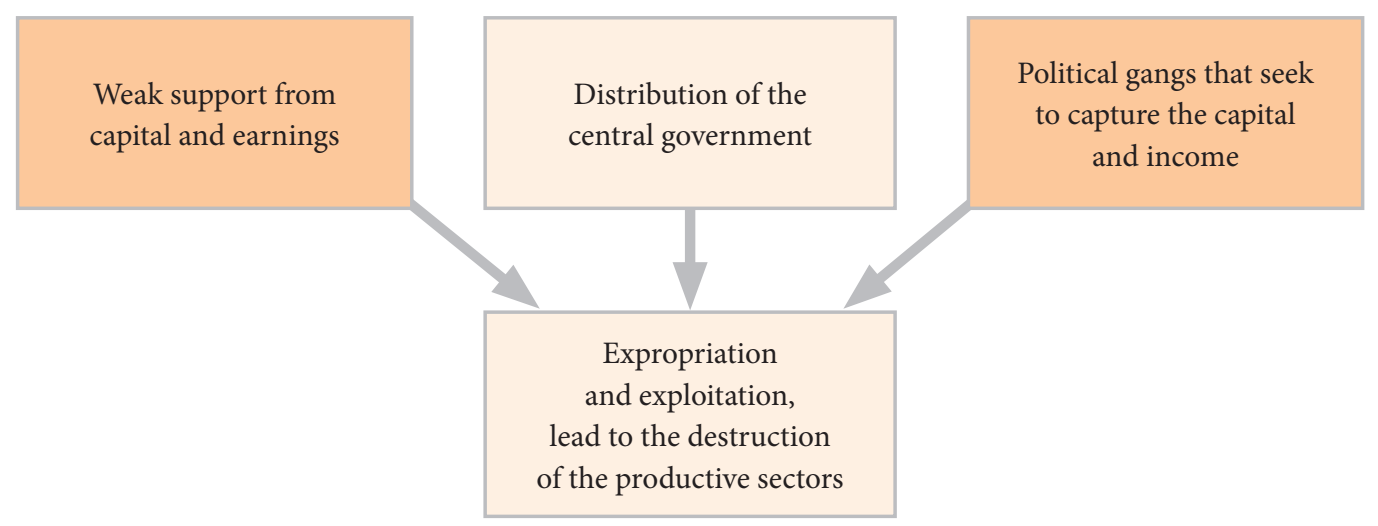


When the government is integrated and it is institutional and political organizations can be consistently compatible with each other, it is unlikely that the common Patron-Client politics or non-market exchanging methods lead to government destruction (Shleifer \& Vishny, 1993). This is solely because the superior governmental organizations, due to their own interests, limit the lower officials or the organizations whose authority threatens their entire interests.

Nevertheless, the main anti-corruption program may ignore some major problems in some of the developing countries. In these countries, transparency, increased salaries, and anti-corruption auditors have no required or necessary effects. Policies and programs in these countries should be based on the creation of a Hobbesian government in a society in which the state is separated from that society, not an emphasis on Adam Smith's reforms that restrict the freedom of the state. This program is strongly based on the greed and power theory for the thousands of permanent problems in developing countries with poor performance.

In this regard, it can be concluded that the decline and fall into exploitation in some of the weakest developing countries is not due to the greed and power of the official, but because of the official inability to impose or implement the desired social order. In those countries, reforms based on an incorrect analysis of the corruption factors can eventually decrease the government's ability to take decisive actions. This analysis does not deny that government legitimacy is very important. In addition, it does not deny that the government that behaves arbitrarily may not be able to impose a social order. This analysis reveals that the main factors that cause such problems should be precisely determined and solved by anti-corruption reforms.

Our discussion about different motivations behind corruption in this section can help to explain the contradiction that all developing countries have a high level of corruption and all of these countries have failed in their early stages of the development in the good governance. These observations can be explained by the argument that many of the corruption and poor governance drivers (such as poor ownership) are structured and therefore they are generally inevitable in all developing countries. However, high-growth countries have potential governance capacities that allow them to avoid most of the destructive aspects of such structural stimuli.

\section{The effect of politics on corruption}

By considering the other motivations, the reforming programs such as liberalization, increased salaries, law domination and transparency do not cause a significant reduction in corruption. However, there is no reason why unnecessary downtime and other malicious interventions should not be targeted or eliminated in developing countries.

Based on necessary state interventions, the reforming programs should be completely different. Historical observation has shown that successful governments suffer from a degree of corruption in these areas, but those countries have powerful government capacities which guarantee the achievement of desir- 
able outcomes. In addition, the cost of the corruption in those countries is not so high as to eliminate the net profit generated by these outcomes. On the other hand, governments with less success cannot fulfill their essential duties effectively and, as a result, the corruption in those areas is very destructive, because the rent seeking cost is added to the poor results. We believe that the reforming programs and policies in this area should focus on strengthening the government capacities and formuling and correcting the economic rent seeking.

In the case of political corruption, all developing countries must tolerate levels of corruption that cannot be solved in the prolonged period. In addition, some strategies should be defined in developing countries to limit this kind of corruption by increasing financial redistribution in order to maintain political stability in a transparent manner. However, the priority of midterm reforms must be to limit the destructive effects of political stability through the PatronClient networks. This problem may be solved in some countries through the restructuring of these political arrangements. It should be noted that this is a completely internal problem that the developing countries must solve on their own terms. The ownership instability and the related corruption is an effective problem in developing countries. But in the high growth countries there is appropriate institutional capacities in order to guarantee stable expectations in the important areas. In other countries, the priority of the reforms should be focused on learning from experiences, to develop the governance necessary capacity, even if a desired level of stability in ownership is not achieved in all of those countries over the years.

Finally, exploitation is the most important threat to developing countries. All successful countries significantly reduced exploitation and increased ownership because they had powerful governments which could stop the lower authorities (officials) or dealers being in contact with the local authorities. Rapid and sustainable development by governments that do not have the ability to impose the social order is not possible. However, there are many examples of fast growing governments that suffer from corruption. Strengthening the executive capacity in states (governments), which are faced with predatory governmental behavior is better than the elimination of inefficient states (governments).

\section{Conclusion}

This paper analyzes whether it is possible to interpret governance plans as a prerequisite for development. The results show that both weak ownership and structural motivations for corruption make it hard to achieve development in a developing country, regardless of their economic performance. According to our analysis, the real danger occurs when those structural motivations are not properly understood. Apart from the mentality of the corruption indicators and the possibility of manipulating them, the studies proved that the negligible differences among those indicators do not reveal the prospects of development in developing countries. Instead, the obtained results proved that in order to accelerate the economic and social changes in the developing countries, the important governance capacities for each country should 
be determined separately. Meanwhile, a framework is required to distinguish between the different types of corruption in order to regulate the possible priorities for reforming national institutions and anti-corruption strategies. In addition, the results revealed that by emphasizing a long list of unachievable goals as urgent corrective priorities, the opportunity for performing the vital reforms is ultimately destroyed. On the other hand, the forming program is at the risk of creating frustration and making it impossible to conduct the reforms, because it seems impossible to achieve its goals.

\section{REFERENCES}

1. Jasabi, J. \& Nafari, N. (2009). Designing a Good Governance Model Based on the Open Systems Theory. Tehran: IRNA. Journal of Management Science, vol. 4, no 16.

2. FarrokhSeresht, B. (2004). Investigating the Factors Affecting Occurrence of Administrative Corruption. Tehran: Management College of Tehran University.

3. Gharani, M et al. (2010). Investigating and Analyzing the Relationship of Corruption with Good Governance Principles and Its Effectiveness from Organizational Culture (Case Study: Administrative Corruption). Proceedings of the Conference on Promoting Occupational Health. Tehran: Zaman Publication.

4. Gholipour, R. (2005). Investigating the Relationship between Good Governance Pattern and Administrative, Corruption. Tehran: Management Culture: Third Year, no 10.

5. Kermani, M. \& Baskhah, M. (2009). The Role of Good Governance in Improving the Function of Government Spending: Case Study of Health and Education Section in Islamic Countries. Tehran: Economic Research, p. 44.

6. Midri, A. (2002). Compatibility of Corporate Governance with Iran Economy, (PhD thesis). Tehran: Economics College of Tehran University.

7. Besley, T. \& McLaren, J. (1993). Taxes and Bribery: The Role of Wage Incentives. The Economic Journal, no 103 (January), p. 119-141.

8. Carothers, T. (2003). Promoting the Rule of Law Abroad: The Problem of Knowledge. Carnegie Endowment for International Peace publication. Washington: Rule of Law Series, no 34. 
9. Gurgur, T. \& Shah, A. (2000). Localization and Corruption: Panacea or a Pandora's Box IMF Conference on Fiscal Decentralization. Washington DC: mimeo publication, November 21.

10. Harriss-White, B. \& White, G. (1996). Corruption, Liberalization and Democracy. IDS Bulletin (Liberalization and the New Corruption), vol. 27, no 2, p. 1-5.

11. Huther, J. \& Shah, A. (2000). Anti-Corruption Policies and Programs: A Framework for Evaluation. Washington. World Bank Operations Evaluation Department publication, Policy Research Working Paper, no 2501.

12. Khan, MH. (2006a). Corruption and Governance. In: Jomo K.S and Fine B.(eds.) The New Development Economics. London, New Delhi: Zed Press, Tulika, p. 200-221.

13. Khan, MH. (2006b). Determinants of Corruption in Developing Countries: the Limits of Conventional Economic Analysis. In: Rose-Ackerman S. (ed.) International Handbook on the Economics of Corruption. Cheltenham, Edward Elgar, p. 216-244.

14. Khan, M.H. (2006c). Governance, Economic Growth and Development since the 1960s: Background paper for World Economic and Social Survey. Washington: United Nation's DESA publication.

15. Knack, S. Keefer, P. (1995). Institutions and Economic Performance: Cross-Country Tests Using Alternative Institutional Measures. Economics and Politics, vol. 7, no 3, p. 207.

16. Krueger, A.O. (1974). The Political Economy of the Rent-Seeking Society. American Economic Review, vol. 64, no 3, pp. 291-303.

17. Rodrick, D. (ed.) (2003). In Search of Prosperity: Analytic Narratives on Economic Growth. Princeton: Princeton University Press.

18. Rose-Ackerman, S. (1978). Corruption: A Study in Political Economy. New York, Academic Press.

19. Shleifer, A \& Vishny, R.W. (1993). Corruption. Quarterly Journal of Economics, vol. 108, no 3, pp. 599-617.

20. World Bank (1993). The East Asian Miracle: Economic Growth and Public Policy. Oxford: Oxford University Press publication. 